\title{
Passive Amyloid Immunotherapy Clears Amyloid and Transiently Activates Microglia in a Transgenic Mouse Model of Amyloid Deposition
}

\author{
Donna M. Wilcock, ${ }^{1,2}$ Amyn Rojiani, ${ }^{1,3,4}$ Arnon Rosenthal, ${ }^{5}$ Gil Levkowitz, ${ }^{5}$ Sangeetha Subbarao, ${ }^{5}$ Jennifer Alamed, ${ }^{1,2}$ \\ David Wilson, ${ }^{1,2}$ Nedda Wilson, ${ }^{1,2}$ Melissa J. Freeman, ${ }^{1,2}$ Marcia N. Gordon, ${ }^{1,2}$ and Dave Morgan ${ }^{1,2}$ \\ ${ }^{1}$ Alzheimer's Research Laboratory and Departments of ${ }^{2}$ Pharmacology, ${ }^{3}$ Interdisciplinary Oncology, and 4 Pathology, University of South Florida, Tampa, \\ Florida 33612, and ${ }^{5}$ Rinat Neuroscience Corporation, Palo Alto, California 94304
}

The role of microglia in the removal of amyloid deposits after systemically administered anti-A $\beta$ antibodies remains unclear. In the current study, we injected Tg2576 APP transgenic mice weekly with an anti-A $\beta$ antibody for 1, 2, or 3 months such that all mice were 22 months at the end of the study. In mice immunized for 3 months, we found an improvement in alternation performance in the $Y$ maze. Histologically, we were able to detect mouse IgG bound to congophilic amyloid deposits in those mice treated with the anti-A $\beta$ antibody but not in those treated with a control antibody. We found that Fc $\gamma$ receptor expression on microglia was increased after 1 month of treatment, whereas CD45 was increased after 2 months of treatment. Associated with these microglial changes was a reduction in both diffuse and compact amyloid deposits after 2 months of treatment. Interestingly, the microglia markers were reduced to control levels after 3 months of treatment, whereas amyloid levels remained reduced. Serum A $\beta$ levels and anti-A $\beta$ antibody levels were elevated to similar levels at all three survival times in mice given anti-A $\beta$ injections rather than control antibody injections. These data show that the antibody is able to enter the brain and bind to the amyloid deposits, likely opsonizing the A $\beta$ and resulting in Fc $\gamma$ receptor-mediated phagocytosis. Together with our earlier work, our data argue that all proposed mechanisms of anti-A $\beta$ antibody-mediated amyloid removal can be simultaneously active.

Key words: Alzheimer's disease; antibody; behavior; microglia; immunization; amyloid $\beta$

\section{Introduction}

Reduction of brain amyloid after anti-A $\beta$ immunotherapy was first demonstrated by Schenk and colleagues (1999). Their report showed that vaccination with $\mathrm{A} \beta_{1-42}$ in the PDAPP transgenic mouse model of Alzheimer's disease dramatically reduced levels of $A \beta$ deposits in the brain. Later it was shown that using the same vaccination protocol in APP + PS1 doubly transgenic mice (Morgan et al., 2000) and in TgCRND8 transgenic mice (Janus et al., 2000) not only reduced $A \beta$ levels in the brain but also protected these mice from memory deficits. More recent studies have demonstrated that passive immunization consisting of direct anti-A $\beta$ antibody injections not only results in dramatic reduction of $A \beta$ levels (Bard et al., 2000; DeMattos et al., 2001) in the brain but also reverses memory deficits in transgenic mouse models of Alzheimer's disease (Dodart et al., 2002; Kotilinek et al., 2002).

The mechanisms by which immunotherapy acts remain unclear. Suggested mechanisms include microglial-mediated

Received March 24, 2004; revised May 12, 2004; accepted May 13, 2004.

This work was supported by National Institute on Aging Grants AG15490 (M.N.G.) and AG18478 (D.M.) from the National Institutes of Health. D.M.W. is a Benjamin scholar in Alzheimer's disease research.

Correspondence should be addressed to Dr. Dave Morgan, Department of Pharmacology, University of South Florida, 12901 Bruce B. Downs Boulevard, MDC Box 9, Tampa, FL 33612. E-mail: dmorgan@hsc.usf.edu. DOI:10.1523/JNEUROSCI.1090-04.2004

Copyright $\odot 2004$ Society for Neuroscience $\quad$ 0270-6474/04/246144-08\$15.00/0 phagocytosis (Schenk et al., 1999; Wilcock et al., 2001, 2003, 2004), disaggregation of amyloid deposits (Solomon et al., 1997; Wilcock et al., 2003, 2004), and removal of $\mathrm{A} \beta$ from the brain by binding of circulating $A \beta$ in plasma with the anti-A $\beta$ antibodies, resulting in a concentration gradient from brain to plasma. This latter mechanism is also known as the peripheral sink hypothesis (DeMattos et al., 2001; Dodart et al., 2002; Das et al., 2003; Lemere et al., 2003).

We have previously reported that after intracranial anti-A $\beta$ antibody injections into APP transgenic mice, there is a rapid removal of diffuse amyloid deposits apparently independent of microglial activation and also a later removal of compact amyloid deposits, which appears to require microglial activation (Wilcock et al., 2003). In fact, in a later study using the same model, administration of dexamethasone, which suppresses microglial activation, anti-A $\beta$ antibody administration inhibited the removal of compact, thioflavine-S-positive amyloid deposits (Wilcock et al., 2004).

In this report, we show that weekly systemic administration of anti-A $\beta$ antibodies for 1,2 , or 3 months results in a dramatic reduction of both diffuse and compact amyloid deposits. Associated with this reduction is a behavioral improvement using the $\mathrm{Y}$ maze task. After 1 month of treatment, there is a large induction of Fc $\gamma$ receptor expression on microglia, and after 2 months of administration, there is an increase in CD45 expression indica- 
tive of microglial activation. We have detected antibody binding to congophilic plaque in APP transgenic mice treated with an anti-A $\beta$ antibody. We also observed a dramatic increase in circulating $A \beta$ levels after 1 month of administration. Two months after administration, we observed a dramatic reduction in compact and diffuse deposits. After 3 months of administration, the microglia markers are down to control levels, whereas the compact and diffuse amyloid deposits remain reduced. These results demonstrate systemically administered anti-A $\beta$ antibodies are accessing the brain, binding to amyloid deposits, and activating microglia. The data also show an increase in circulating $A \beta$ in plasma, consistent with the peripheral sink hypothesis.

\section{Materials and Methods}

Experiment design. Singly transgenic APP Tg2576 mice were obtained from our breeding program at University of South Florida, started in 1996 (Holcomb et al., 1998). Twenty-two APP transgenic mice aged 19 months were assigned to one of four experimental groups. The first three groups received weekly intraperitoneal anti- $\mathrm{A} \beta$ antibody injections (antibody 2286, mouse monoclonal anti-human $\mathrm{A} \beta_{28-40}$ IgG1; Rinat Neuroscience Corporation) for 1 month $(n=6), 2$ months $(n=9)$, or 3 months $(n=4)$. The fourth group received weekly intraperitoneal antiAMN antibody injections (2906; mouse monoclonal anti-Drosophila amnesiac protein IgG1; Rinat Neuroscience Corporation) for 3 months $(n=3)$. Twelve nontransgenic mice were assigned to one of two experimental groups. The first group received intraperitoneal anti-A $\beta$ antibody injections for 3 months $(n=4)$. The second group received no treatment $(n=3)$. All mice were given a dose of $10 \mathrm{mg} / \mathrm{kg}$ of the appropriate antibody. Treatment of 1 and 2 month groups was delayed to insure the mice were killed at the same age ( 22 months). One week before killing and $1 \mathrm{~d}$ after the 5th, 9th, or 13th injection, mice were tested behaviorally using the $\mathrm{Y}$ maze task.

Behavioral testing. The $\mathrm{Y}$ maze is a three-arm maze with equal angles between all arms. Mice were initially placed within one arm, and the sequence and number of arm entries were recorded for each mouse over an $8 \mathrm{~min}$ period. The percentage of triads in which all three arms were represented $(\mathrm{ABC}, \mathrm{CAB}$, or $\mathrm{BCA}$ but not $\mathrm{BAB})$ was recorded as an alternation to estimate short-term memory of the last arms entered. The total number of possible alternations is the number of arm entries minus two. Additionally, the number of arm entries serves as an indicator of activity.

Antibody purification. Antibody 2286 (mouse monoclonal antihuman $\mathrm{A} \beta_{28-40} \mathrm{IgG1}$ ) and antibody 2906 (mouse monoclonal antiDrosophila amnesiac protein IgG1) were purified from mouse ascites on AKTA instrumentation using protein A beads (MabSelect; Amersham Biosciences, Arlington Heights, IL). Briefly, ascites was filtered in a pyrogen-free $0.22 \mu \mathrm{m}$ filter system (Corning, Corning, NY) and applied to a $20 \mathrm{ml}$ bed volume in an XK16/20 column (Amersham Biosciences) after equilibrating the beads with $5 \mathrm{vol}$ of binding buffer $(0.6 \mathrm{M} \mathrm{NaCl}$ and $0.3 \mathrm{~m}$ glycine, $\mathrm{pH}$ 8.0). The column was washed with $3 \mathrm{vol}$ of binding buffer, and the antibody was eluted in 4 vol of elution buffer $(0.1 \mathrm{M} \mathrm{Na}$ citrate, $\mathrm{pH}$ 3.0) and held at low $\mathrm{pH}$ for $30 \mathrm{~min}$ for viral inactivation. The resulting eluant was neutralized with $0.1 \mathrm{vol}$ of $1.0 \mathrm{~m}$ Tris, $\mathrm{pH} 9.5$. The antibody was dialyzed into sterile PBS, $\mathrm{pH} 7.4$, and the concentration was determined by reading absorbance at $280 \mathrm{~nm}$. All buffers were made in pyrogen-free water.

Tissue preparation. On the day of killing, mice were weighed and overdosed with $100 \mathrm{mg} / \mathrm{kg}$ pentobarbital (Nembutal sodium solution; Abbott Laboratories, North Chicago, IL). Blood was collected and allowed to coagulate at $4^{\circ} \mathrm{C}$ for at least $1 \mathrm{hr}$ before being centrifuged, and the serum was removed and stored at $-80^{\circ} \mathrm{C}$ until required. The mice were then intracardially perfused with $25 \mathrm{ml}$ of $0.9 \%$ sodium chloride. Brains were rapidly removed, and the right half of the brain was dissected and frozen for biochemistry, whereas the left half of the brain was immersion-fixed for $24 \mathrm{hr}$ in freshly prepared $4 \%$ paraformaldehyde in $100 \mathrm{mM} \mathrm{PO}_{4}, \mathrm{pH}$ 7.2 , for histopathology. The latter hemibrains were then incubated for 24 $\mathrm{hr}$ in 10,20 , and $30 \%$ sucrose sequentially to cyroprotect them. Horizontal sections of $25 \mu \mathrm{m}$ thickness were collected using a sliding microtome and stored at $4^{\circ} \mathrm{C}$ in Dulbecco's PBS with sodium azide, $\mathrm{pH}$ 7.2, to prevent microbial growth.

ELISA methods: $A \beta$ and anti- $A \beta$ antibody. For the $A \beta$ assay, serum was diluted and incubated in 96-well microtiter plates (MaxiSorp; Nunc, Rosklide, Denmark), which were precoated with antibody 6E10 (Signet, Dedham, MA) at $5 \mu \mathrm{g} / \mathrm{ml}$ in PBS buffer, $\mathrm{pH}$ 7.4. The secondary antibody was biotinylated 4G8 (Signet) at a 1:5000 dilution. Detection was done using a streptavidin-horseradish peroxidase conjugate (Amersham Biosciences), followed by TMB substrate (KPL, Gaithersburg, MD). Standard curves of $\mathrm{A} \beta_{1-40}$ (Global Peptide, Ft. Collins, CO) scaling from 6-400 pm were used.

The anti-A $\beta$ antibody was dissociated from endogenous $A \beta$ in serum as described previously ( $\mathrm{Li}$ et al., 2004). Briefly, serum was diluted in dissociation buffer (0.2 $\mathrm{M}$ glycine $\mathrm{HCl}$ and $1.5 \% \mathrm{BSA}, \mathrm{pH} 2.5)$ and incubated at room temperature for $20 \mathrm{~min}$. The sera were pipetted into the sample reservoir of a Microcon centrifugal device (10,000 molecular weight cutoff; YM-10; Millipore, Bedford, MA) and centrifuged at $8000 \times g$ for $20 \mathrm{~min}$. at room temperature. The sample reservoir was then separated from the flow-through, placed inverted into a second tube, and centrifuged at $1000 \times g$ for $3 \mathrm{~min}$. The collected solution containing the antibody dissociated from the $\mathrm{A} \beta$ peptide was neutralized to $\mathrm{pH} 7.0$ with $1 \mathrm{~m}$ Tris buffer, $\mathrm{pH}$ 9.5. The dissociated sera were assayed by ELISA for antibody titer. $\mathrm{A} \beta_{1-40}$ (Global Peptide)-coated 96-well microtiter plates (MaxiSorp; Nunc) were incubated with dissociated serum samples. A biotinylated goat-anti mouse IgG (heavy and light chain; Vector Laboratories, Burlingame, CA) at a 1:5000 dilution followed by peroxidaseconjugated streptavidin (Amersham Biosciences) was used to detect serum anti-A $\beta$ binding activity.

Immunohistochemical methods. A series of eight equally spaced tissue sections $2.4 \mathrm{~mm}$ apart were randomly selected, spanning the entire brain, and stained using free-floating immunohistochemistry methods for total A $\beta$ (rabbit polyclonal anti-pan-A $\beta, 1: 10,000$; Bisource, Camarillo, CA), CD45 (rat anti-mouse CD45, 1:3000; Serotec, Raleigh, NC), and Fc $\gamma$ receptors II and III (rat anti-mouse CD16 and CD32, 1:3000; BD PharMingen, San Diego, CA) as previously described (Gordon et al., 2002). Briefly, tissue was incubated in primary antibody overnight at room temperature. Sections were then washed and incubated in the appropriate biotinylated secondary antibody (for $\mathrm{A} \beta$, goat anti-rabbit, 1:3000; for CD45 and Fc $\gamma \mathrm{R}$, goat anti-rat, 1:1000; all Vector Laboratories) for $2 \mathrm{hr}$. After multiple washes, tissue was incubated in ABC (Vector Laboratories) for $1 \mathrm{hr}$. Color development was performed using 3,3'-diaminobenzidine (DAB; Sigma, St. Louis, MO) enhanced with nickelous ammonium sulfate (J. T. Baker Chemical Company, Phillipsburg, NJ) for $\mathrm{CD} 45$ and $\mathrm{Fc} \gamma \mathrm{R}$ or without enhancement for $\mathrm{A} \beta$. For immunostaining, some sections were omitted from the primary antibody to assess nonspecific immunohistochemical reactions.

Additional sections were also stained for mouse IgG using immunohistochemical methods similar to that described above. Briefly, sections were incubated overnight in a 1:3000 concentration of anti-mouse IgG conjugated to horseradish peroxidase (Sigma). The sections were then washed and incubated for $5 \mathrm{~min}$ in $100 \mathrm{ml}$ of Tris-buffered saline containing $50 \mathrm{mg}$ of DAB (Sigma), $500 \mathrm{mg}$ of nickelous ammonium sulfate (J. T. Baker Chemical Company), and $100 \mu \mathrm{l}$ of 30\% hydrogen peroxide to produce a purple-black color reaction product. The sections were then mounted on slides and counterstained with a $0.2 \%$ Congo red solution in $80 \%$ ethanol to assess the localization of positive mouse IgG stain with compact amyloid deposits.

A set of sections was also mounted and stained using $0.2 \%$ Congo red solution in $\mathrm{NaCl}$-saturated $80 \%$ ethanol. Another set of sections was also mounted and stained using $4 \%$ thioflavine-S (Sigma) for $10 \mathrm{~min}$.

The immunohistochemical reaction product on all sections was measured using Image-Pro Plus version 4.5 software (Media Cybernetics, Silver Spring, MD). One region of the frontal cortex for all sections from each animal was analyzed, and an average of six or seven sections was taken to give a value for each animal. Three regions of the hippocampus were analyzed on approximately four or five sections where hippocampus was present: cornu ammonis 1 (CA1), CA3, and dentate gyrus. These regions were analyzed both individually to yield an average per region and also combined to give an overall value for the hippocampus for each 

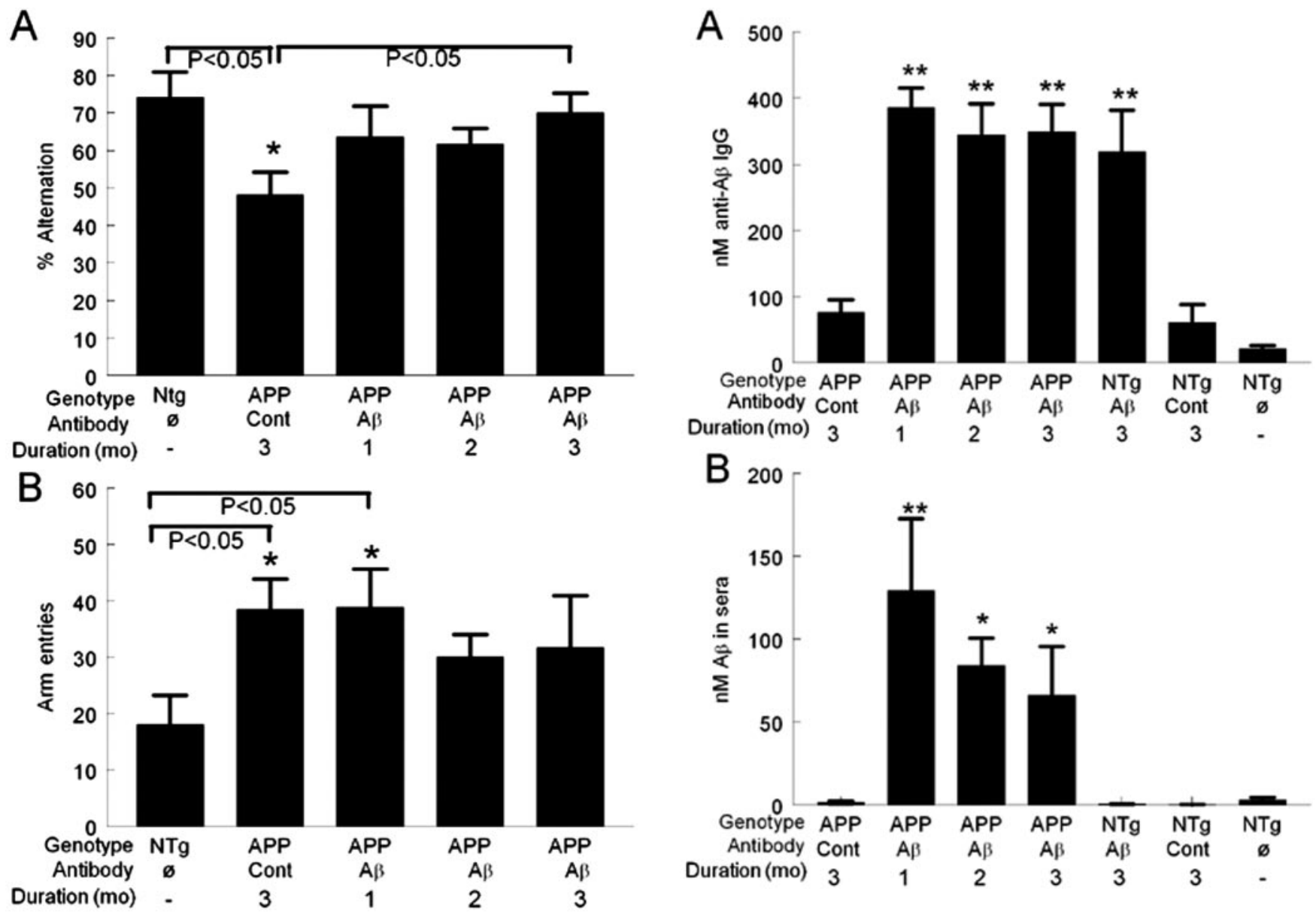

Figure 1. Y maze behavioral improvement after systemic anti-A $\beta$ antibody administration. $A$, Percent alternation for nontransgenic $(\mathrm{NTg})$ mice receiving no treatment (ø), APP transgenic mice (APP) receiving the control antibody (Cont) for 3 months, and APP transgenic mice (APP) receiving the anti-A $\beta(A \beta)$ antibody for 1,2 , or 3 months. ${ }^{*} p<0.05$ when compared with nontransgenic untreated mice and APP transgenic mice receiving the anti-A $\beta$ antibody for 3 months. $B$, Number of arm entries for nontransgenic mice receiving no treatment, APP transgenic mice receiving the control antibody for 3 months, and APP transgenic mice receiving the anti-A $\beta$ antibody for 1,2 , or 3 months. ${ }^{*} p<0.05$ when compared with nontransgenic untreated mice.

animal. This ensured that there was no regional bias in the hippocampal values. These same analysis methods were also used to evaluate the Congo red stain. To assess possible treatment-related differences, the values for each treatment group were analyzed by one-way ANOVA followed by Fisher's least significant difference (LSD) means comparisons. Nontransgenic mice showed no treatment-related differences in any histological analyses, so these groups were pooled.

Data analysis. Percent alternation and arm entry numbers from the $\mathrm{Y}$ maze behavior task were analyzed using one-way ANOVA followed by Fisher's LSD means comparisons using StatView software version 5.0.1 (SAS Institute Inc., Cary, NC). Nontransgenic mice showed no treatment-related differences in any behavioral analyses, so these groups were pooled. ELISA values for serum $A \beta$ levels and circulating antibody levels were analyzed using one- ANOVA followed by Fisher's LSD means.

\section{Results}

Transgenic APP mice given control antibody injections showed significantly reduced $\mathrm{Y}$ maze alternation when compared with the nontransgenic mice (Fig. $1 A$ ). This reduced alternation was reversed in the APP transgenic mice receiving weekly anti-A $\beta$ antibody injections for 3 months. This group of mice was indistinguishable from the nontransgenic animals and showed signif-

Figure 2. Increased serum levels of anti-A $\beta$ antibody and $A \beta$ after anti-A $\beta$ antibody administration. $A$, Amounts of circulating anti-A $\beta$ antibodies in APP transgenic mice (APP) receiving either the control antibody (Cont) for 3 months or the anti- $A \beta$ antibody (A $\beta$ ) for 1, 2, or 3 months, nontransgenic (NTg) mice receiving either the control antibody or the anti- $A \beta$ antibody for 3 months, and nontransgenic mice receiving no treatment. ${ }^{* *} p<0.001$ compared with APP mice given control antibody injections. $B$, Amounts of circulating $A \beta$ in sera in APP transgenic mice receiving either the control antibody for 3 months or the anti- $A \beta$ antibody for 1, 2, or 3 months, nontransgenic mice receiving the either control antibody (Cont) or the anti-A $\beta$ antibody for 3 months, and nontransgenic mice receiving no treatment. ${ }^{* *} p<0.01$; ${ }^{*} p<0.05$.

icantly increased alternation compared with the APP transgenic mice receiving the control antibody (Fig. $1 A$ ). The APP transgenic mice given weekly anti-A $\beta$ antibody injections for either 1 or 2 months were intermediate between nontransgenic and transgenic mice given control antibodies and not significantly different from either group. Nontransgenic mice also made significantly fewer arm entries than the APP transgenic mice receiving control antibody injections, indicating hyperactivity in the APP transgenic mice. The APP transgenic mice receiving anti-A $\beta$ antibody injections for 2 and 3 months did not exhibit this hyperactivity and were not significantly different from any other treatment groups (Fig. 1B).

One day after anti- $\mathrm{A} \beta$ antibody administration, anti- $\mathrm{A} \beta$ antibodies were detected in serum at high levels $(400 \mathrm{nM})$ after 1 month of administration. This level of antibody in the serum was the same after 2 or 3 months of administration, with no apparent accumulation of the antibody (Fig. 2A). Associated with high anti-A $\beta$ antibody levels in serum at 1 month was a dramatic increase in circulating A $\beta$ levels in serum. APP transgenic mice receiving the control antibody had only $1.5 \mathrm{nM}$ circulating $\mathrm{A} \beta$ in 


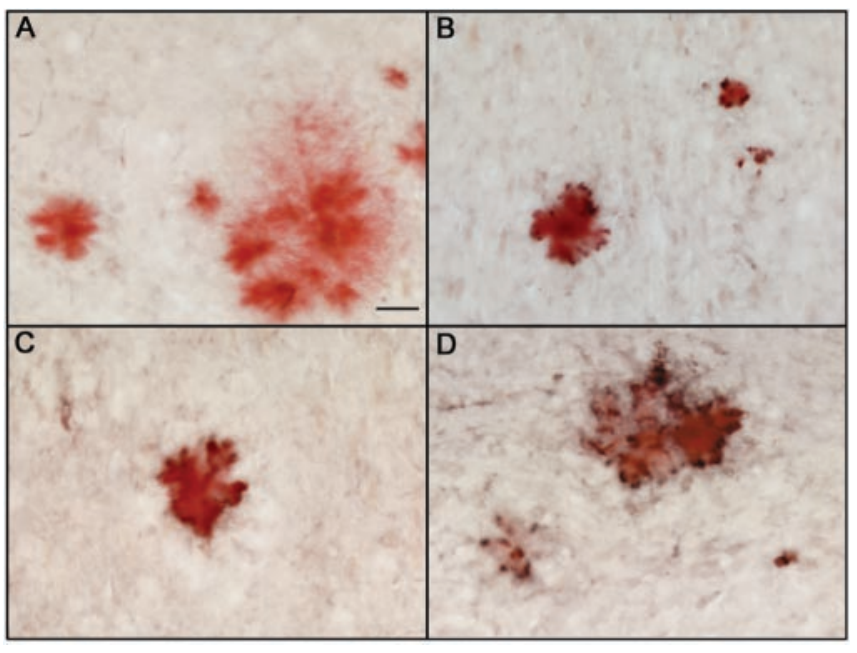

Figure 3. Mouse $\lg \mathrm{G}$ immunohistochemistry showing antibody binding to Congophilic plaques in anti-A $\beta$ antibody-treated mice but not control antibody-treated mice. $A-D$, Antimouse lgG-HRP immunohistochemistry counterstained with Congo red to detect compact amyloid deposits. $A$, Representative amyloid deposit and associated anti-mouse lgG immunostaining (black) in the hippocampus of a mouse injected with the control antibody for 3 months. $B-D$, Representative amyloid deposit (red) associated with anti-mouse lgG immunostaining (black) in the hippocampus of a mouse injected with the anti-A $\beta$ antibody for 1 month $(B), 2$ months (C), or 3 months (D). Magnification, $200 \times$. Scale bar, $25 \mu \mathrm{m}$.

plasma compared with APP transgenic mice receiving the $\mathrm{A} \beta$ antibody for 1 month, which had $130 \mathrm{~nm}$ circulating $\mathrm{A} \beta$ in plasma, an almost 100 -fold increase (Fig. $2 B$ ). Despite similar levels of anti-A $\beta$ antibody at 1,2 , or 3 months of administration, circulating $A \beta$ levels declined between 1 and 2 months. They also showed a slight decline between 2 and 3 months of administration, although with both 2 and 3 months of administration, circulating $A \beta$ levels were still significantly elevated compared with APP transgenic mice receiving the control antibody (Fig. $2 B$ ).

After systemic administration of anti-A $\beta$ antibodies weekly for 1 month, staining for mouse IgG could be detected on plaques throughout the brains of APP transgenic mice (Fig. 3B). The staining was the most intense where plaque load was greatest: the hippocampus and frontal cortex. This staining was not observed in APP transgenic mice receiving the control antibody (Fig. $3 A$ ). It should be noted that staining with higher concentrations of anti-mouse IgG-HRP did show staining of plaques in both control-treated and anti-A $\beta$ treated APP transgenic mice. Staining for mouse IgG was still present and slightly more intense around the plaques that remained after 2 (Fig. 3C) and 3 (Fig. 3D) months of treatment.

Total A $\beta$ immunohistochemistry in the APP transgenic mice receiving control antibody (Fig. $4 A$ ) showed a few intensely stained deposits, suggesting compacted amyloid deposits along with more numerous diffuse deposits. There was a concentration of deposits around the hilus of the hippocampus as well as the molecular layers of Ammon's horn. This was a typical amount and distribution of $\mathrm{A} \beta$ for APP transgenic mice of this age, as previously described (Hsiao et al., 1996; Gordon et al., 2002). After 1 month of weekly anti-A $\beta$ antibody injections, there appeared to be a slight reduction in $\mathrm{A} \beta$ immunohistochemistry in the hippocampus (Fig. $4 B$ ), although this was not statistically significant (Fig. 4E). The reduction appeared to be primarily diffuse deposits, with most of the compact amyloid deposits remaining (Fig. $4 B$ ). After 2 months of weekly anti-A $\beta$ antibody injections, we observed a dramatic reduction in $\mathrm{A} \beta$ immunohis- tochemistry, which appeared to be both compact and diffuse amyloid deposits from the hilus and dentate gyrus regions of the hippocampus as well as the pyramidal cell regions, with only a few deposits remaining, often in the vicinity of the hippocampal fissure and outer molecular layers (Fig. 4C). This reduction in $\mathrm{A} \beta$ load at 2 months was $\sim 60 \%$ in the hippocampus and $~ 55 \%$ in the frontal cortex (Fig. $4 E$ ) (hippocampus, $p<0.001$; frontal cortex, $p<0.005)$. Total $\mathrm{A} \beta$ levels remained reduced after 3 months of treatment but did not appear to decrease any further (Fig. 4D,E).

Congo red staining detects only compact amyloid deposits in the $\beta$ pleated sheet structure. There were far fewer Congo redpositive amyloid deposits than $\mathrm{A} \beta$ deposits detected by total $\mathrm{A} \beta$ immunohistochemistry. Congo red-positive deposits were located primarily along the fissure of the hippocampus as well as the CA1/subiculum region in APP transgenic mice receiving the control antibody (Fig. 5A). There was no reduction in Congophilic deposits 1 month after treatment in either the hippocampus (Fig. 5B,E) or the frontal cortex (Fig. 5E). After 2 months of treatment, there was a significant reduction in both the number and size of Congophilic deposits in both the hippocampus (Fig. $5 C, E$ ) and frontal cortex (Fig. $5 E$ ). This reduction was $\sim 60 \%$ in the frontal cortex and $\sim 50 \%$ in the hippocampus (Fig. $5 E$ ) (frontal cortex, $p<0.005$; hippocampus, $p<0.01$ ). There was a small further reduction between 2 and 3 months, which was $\sim 30 \%$ in the hippocampus and frontal cortex (Fig. 5E). Thioflavine-S staining was also measured and confirmed the Congo red data, showing the same reductions in the stained area as did Congo red (data not shown).

Immunohistochemical staining for Fc $\gamma$ receptors II and III in APP transgenic mice receiving control antibody treatment for 3 months showed only very faint staining of microglia in close association with amyloid deposits (Fig. 6A). After 1 month of anti-A $\beta$ antibody administration, there was a dramatic induction of Fc $\gamma$ receptors II and III on microglia. The microglia expressing the Fc $\gamma$ receptors after 1 month of treatment were not only associated with amyloid deposits but also diffusely distributed (Fig. $6 B$ ). This induction averaged 100 -fold in the hippocampus (Fig. $6 B, E)(p<0.05)$ and frontal cortex (Fig. 6E) $(p<0.05)$. Fc $\gamma$ receptor expression levels fell only slightly between 1 and 2 months of treatment, although this expression was once again concentrated on microglia around remaining amyloid deposits (Fig. $6 D$ ). Induction remained $\sim 100$-fold in the hippocampus (Fig. $6 E)(p<0.05)$ and frontal cortex (Fig. $6 E)(p<0.05)$. After 3 months of treatment, Fc $\gamma$ receptor expression was reduced to levels observed in APP transgenic mice receiving the control antibody (Fig. 6E), although it appeared to be increased in microglia around the few remaining amyloid deposits (Fig. 6D).

CD45, a protein-tyrosine phosphatase, is normally moderately expressed on microglia around amyloid deposits in aged APP transgenic mice and is a commonly used marker for microglial activation. This moderate expression was observed in the APP transgenic mice receiving control antibody treatment for 3 months (Fig. 7A,E). After 1 month of treatment, we observed an increase in CD45 expression on microglia surrounding amyloid deposits in both the hippocampus (Fig. 7B,F,I) and frontal cortex (Fig. 7I). Although expression in the hippocampus was $\sim 2.5$ times that observed in control-treated APP transgenic mice (Fig. 7I) (not significant) and twice the values found in the frontal cortex of control animals, the elevation was not statistically significant (Fig. 7I). After 2 months of anti-A $\beta$ antibody treatment, there was an additional increase in CD45 expression on microglia not only surrounding the amyloid deposits but also diffusely dis- 
tributed throughout the amyloidcontaining brain regions (Fig. $7 C, G$ ). It is possible that this more widespread activation is in association with diffuse amyloid deposits, although we cannot confirm this. The increased expression was $\sim 3.5$ times that observed in control-treated mice in the hippocampus (Fig. 7I) $(p<0.05)$ and 3 times in the frontal cortex (Fig. $7 I)(p<$ $0.01)$. After 3 months of anti-A $\beta$ antibody treatment, CD45 expression remained at the same levels as that observed after 1 month of treatment (Fig. 7I); however, the microglia were still diffusely distributed, with fewer microglia around deposits compared with 1 or 2 months of treatment (Fig. 7D,H).

\section{Discussion}

The data presented here suggest that peripherally administered anti-A $\beta$ antibodies entered the brain, bound to congophilic amyloid plaques, and led to removal of deposited amyloid. In support of the argument that anti-A $\beta$ antibodies entered the brain, we found mouse IgG marking the remaining congophilic amyloid plaques of APP transgenic mice administered the anti-A $\beta$ antibody but no IgG in APP transgenic mice administered the control antibody. This difference was best discerned when low titers of the antimouse IgG-HRP were used. Seabrook et al. (2004) also reported immunohistochemical labeling of amyloid deposits for mouse IgG after passive immunization but detected signals in both immunized and nonimmunized mice. It is unclear whether lower anti-mouse IgG concentrations might have revealed selective staining in anti-A $\beta$-treated animals. These data confirm in parafomaldehyde-fixed tissue the observations of Bard et al. (2000), who used unfixed cryostat sections.

Associated with the presence of the antibody in the brain after 1 month of treatment was a dramatic activation of Fc $\gamma$ receptor expression on microglia, further arguing that anti-A $\beta$ antibodies entered the brain and opsonized the amyloid deposits. Later, after 2 months of treatment, we observed an increase in CD45 expression on microglia, indicating activation of these cells beyond the level normally associated with amyloid deposits. It has previously been shown that after active immunization with $\mathrm{A} \beta_{1-42}$ in humans, anti-A $\beta$ antibodies are present in CSF, in some instances equal to the serum concentration, suggesting some penetration into the brain from the periphery (Hock et al., 2002). It has also been shown that $0.1 \%$ of an intravenous injection of a radiolabeled anti-A $\beta$ antibody crosses the blood-brain barrier of SAMP8 mice (Banks et al., 2002). Thus, accumulating data indicate that circulating antibodies can access the brain parenchyma, which has important implications not only for the use of immunotherapy in Alzheimer's disease but also for other dis-

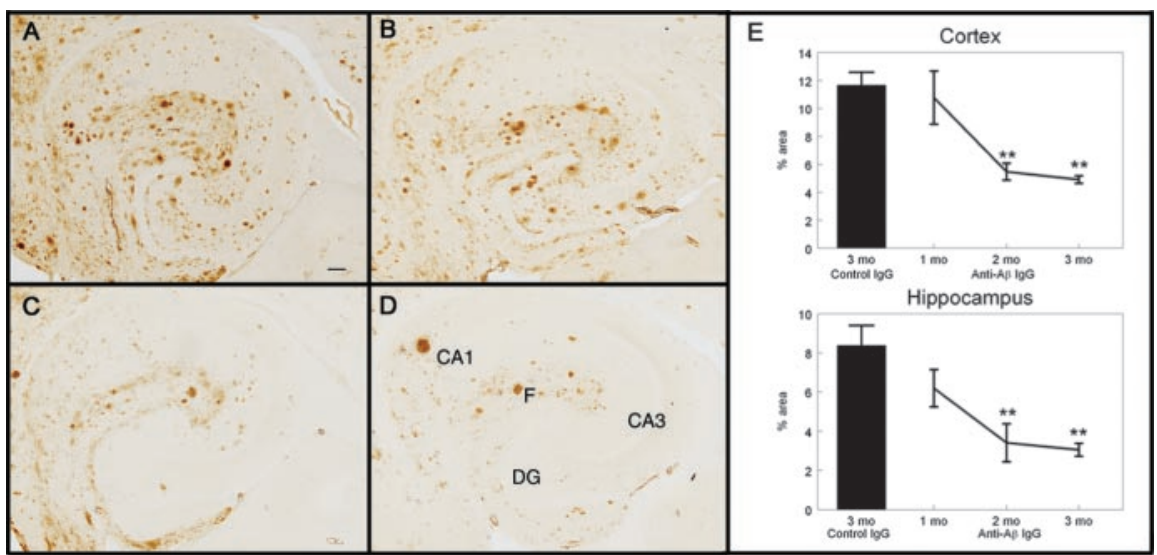

Figure 4. Total $A \beta$ immunohistochemistry is reduced after 2 months of systemic anti- $A \beta$ antibody administration. $A-D$, Total antibody for 2 months ( $C$; percent area for this section was 3.23\%), or the anti-A $\beta$ antibody for 3 months ( $D$; percent area for this ion was 2.49\%). Magnification, $40 \times$. Scale bar, $120 \mu \mathrm{m}$. E, Quantification of the percent area occupied by the $A \beta$-positive

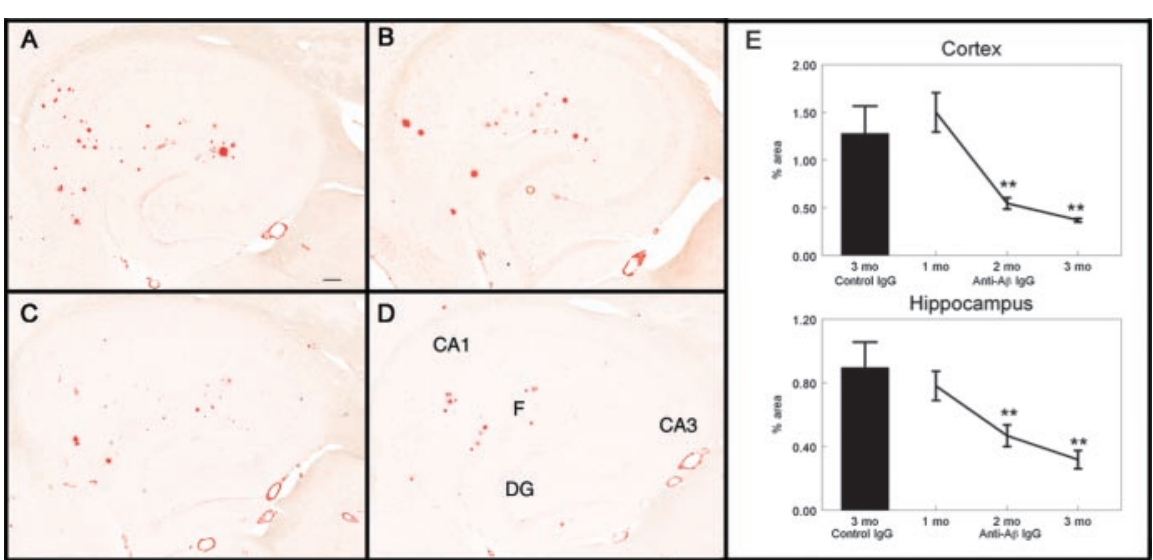

Figure 5. Congophilic compact amyloid plaques are reduced after 2 months of anti-A $\beta$ antibody administration. $A-D$, Congo 1 month $(B)$, the anti- $A \beta$ antibody for 2 months $(C)$, or the anti-A $\beta$ antibody for 3 months $(D)$. Magnification, $40 \times$. Scale bar, $120 \mu \mathrm{m}$. E, Quantification of the percent area occupied by the Congo red-positive stain in the frontal cortex and hippocampus. The transgenic mice receiving the anti-A $\beta$ antibody for 1,2 , and 3 months. ${ }^{* *} p<0.01$. CA1, Cornu ammonis 1 ; CA3, cornu ammonis 3; DG, dentate gyrus; F, hippocampal figure.

eases in which immunotherapy is being pursued, such as Creutzfeldt-Jakob disease (Manuelidis, 1998; Sigurdsson et al., 2003) and neural infections associated with human immunodeficiency virus (McMichael and Hanke, 2003).

Associated with the changes in microglial markers was a significant reduction in both compact and diffuse amyloid deposits after 2 months of treatment; these remained reduced after 3 months of treatment. Removal of $\mathrm{A} \beta$ deposits from the brain appeared to be a gradual process. We did not observe significant reductions in either diffuse or compact amyloid deposits after 1 month of weekly anti-A $\beta$ antibody treatment. After 2 months of treatment, there was a dramatic reduction in total $\mathrm{A} \beta$ immunohistochemistry, Congo red staining, and thioflavine-S staining, suggesting removal of both diffuse and compact amyloid deposits. There appeared to be no accumulation of the injected antibody because serum anti-A $\beta$ antibody levels were the same re- 


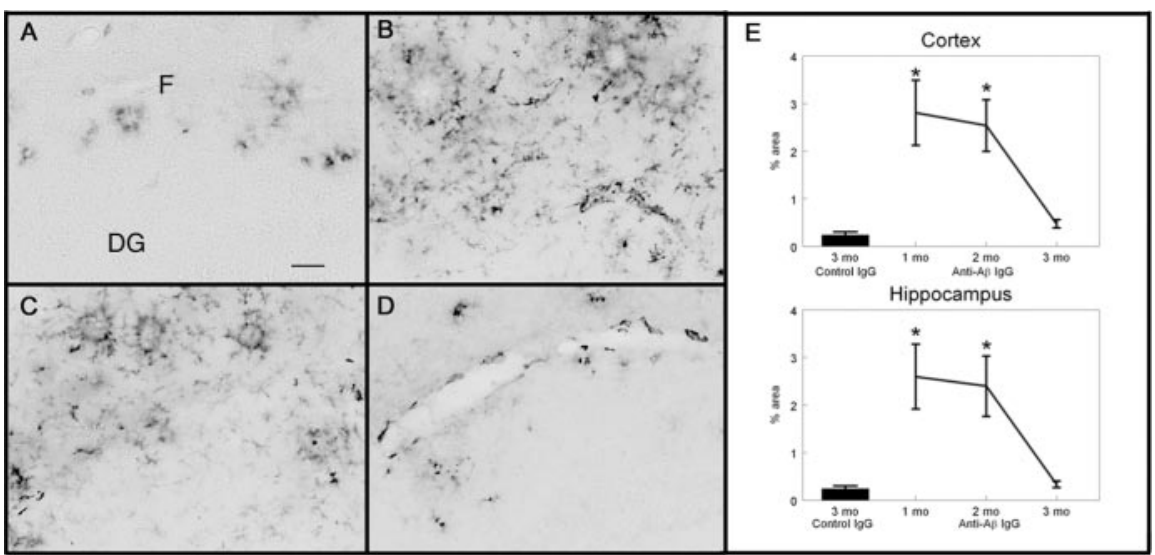

Figure 6. $\quad F c \gamma$ receptor expression on microglia is increased after 1 month of anti-A $\beta$ antibody treatment and remains increased after 2 months of treatment. $A-D, F c \gamma$ receptor immunohistochemistry in the hippocampus of APP transgenic mice receiving the control antibody for 3 months $(A)$, the anti-A $\beta$ antibody for 1 month $(B)$, the anti- $A \beta$ antibody for 2 months $(C)$, or the anti-A $\beta$ antibody for 3 months (D). Magnification, $100 \times$. Scale bar, $50 \mu \mathrm{m}$. E, Quantification of the percent area occupied by the Fc $\gamma$ receptor-positive stain in the frontal cortex and hippocampus. The single bar shows the value for APP transgenic mice receiving the control antibody for 3 months. The line shows the values for APP transgenic mice receiving the anti-A $\beta$ antibody for 1,2 , and 3 months. ${ }^{*} p<0.05$. DG, Dentate gyrus; $F$, hippocampal fissure.

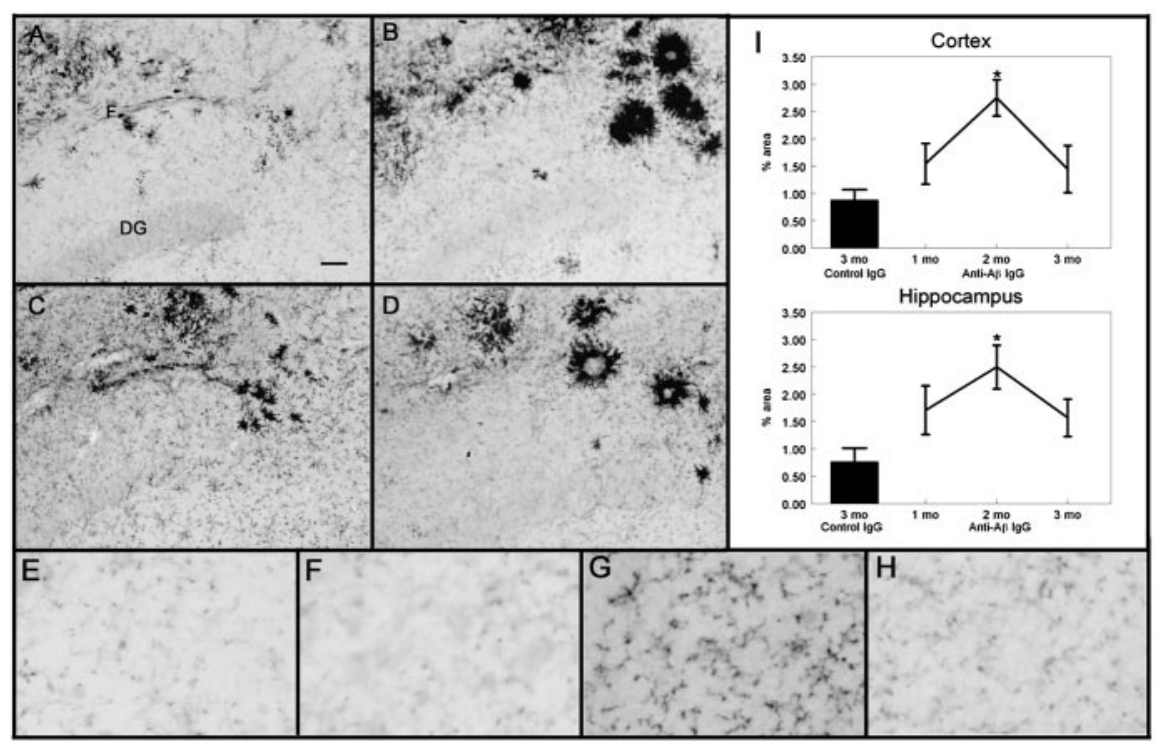

Figure 7. CD45 expression on microglia is increased after 2 months of anti-A $\beta$ antibody treatment. $A-D, C D 45$ immunohistochemistry in the hippocampus of APP transgenic mice receiving the control antibody for 3 months $(A)$, the anti-A $\beta$ antibody for 1 month $(B)$, the anti-A $\beta$ antibody for 2 months $(C)$, or the anti-A $\beta$ antibody for 3 months $(D)$. $F$, Hippocampal fissure; DG, dentate gyrus. Magnification, $100 \times$. Scale bar, $50 \mu \mathrm{m}$. $E-H$, Magnified images of non-amyloid-containing areas from $A-D$, showing $C D 45$ immunohistochemistry in the hippocampus of APP transgenic mice receiving the control antibody for 3 months $(E)$, the anti-A $\beta$ antibody for 1 month $(F)$, the anti-A $\beta$ antibody for 2 months $(G)$, or the anti-A $\beta$ antibody for 3 months $(H)$. I, Quantification of the percent area occupied by the CD45-positive stain in the frontal cortex and hippocampus. The single bar shows the value for APP transgenic mice receiving the control antibody for 3 months. The line shows the values for APP transgenic mice receiving the anti-A $\beta$ antibody for 1,2 , and 3 months. ${ }^{*} p<0.05$.

gardless of the duration of treatment. This would suggest that this time-dependent removal of amyloid deposits was not occurring because of increasing antibody levels; rather, it appears that some mobilization of removal mechanisms must be present for some time before significant removal is apparent.

An early feature we observed was the increase in $\mathrm{Fc} \gamma$ receptor II and III (CD16 and CD32) expression on microglia, which was apparent after 1 and 2 months of treatment. The murine Fc $\gamma$ receptors II and III share a high affinity for IgG1 antibodies (the isotype used in the current study) as well as IgG2a (Gessner et al.,
1998). Following this increased Fc $\gamma$ receptor expression was an increase in CD45 expression on microglia after 2 months of treatment. CD45 is a protein-tyrosine phosphatase, which is elevated with microglial activation. In this study, it appears that the increase in CD45 expression represents a further activation step from that seen after 1 month of treatment, at which we observed the increased Fc $\gamma$ receptor expression. After 3 months of treatment, both Fc $\gamma$ receptor and CD45 expression on microglia were reduced to control levels, possibly because of the substantial reduction in amyloid deposits. It is important to note that if we had looked at only the 3 month point, we would not have detected the activation of the microglia by CD45 or, likely, by other markers such as Mac-1 (Das et al., 2003).

We have previously observed a similar loss of microglia activation after intracranial antibody administration (Wilcock et al., 2003) and active immunization (Wilcock et al., 2001). Three days after a single injection of anti-A $\beta$ antibody in the frontal cortex and hippocampus, we observed an increase in CD45 expression; however, $7 \mathrm{~d}$ after injection, the CD45 expression was reduced to control levels, in parallel with clearance of the $A \beta$ deposits (Wilcock et al., 2003). This suggests that the reduced microglial activation could possibly be attributable to the clearance of most amyloid plaques. It is also conceivable that the microglia could be undergoing apoptosis attributable to the robust activation, as has been described previously by Liu et al. (2001), when microglia are overactivated by lipopolysaccharide. An alternative explanation could be tolerance of the microglia to antibody-opsonized $\mathrm{A} \beta$. We have previously shown a reduction in microglial reaction in an active immunization model using doubly transgenic APP + PS1 mice. After five monthly inoculations, we observed a significant increase in CD45 expression; however, after nine monthly inoculations, CD45 levels were comparable with those of control animals despite continued high antibody titer levels (Wilcock et al., 2001).

Because of the inflammatory adverse effects seen in a human clinical trial of the active immunization by Elan Pharmaceuticals (Ferrer et al., 2004), it could be suggested that the microglial activation observed in this study was attributable to an immune response unrelated to opsonization of $\mathrm{A} \beta$ by the antibody. To evaluate whether this was the case, we examined the thalamus and cerebellum, which do not contain any amyloid deposits, for any increase in CD45 or Fc $\gamma$ receptor expression and did not observe any such increase. Thus, it appears that the microglial activation is specific to amyloidcontaining brain regions and is likely a specific response to opso- 
nized $\mathrm{A} \beta$ as opposed to a general nonspecific inflammatory reaction.

The data presented here extend our previous observations of the benefits of active anti-A $\beta$ immunization on learning and memory (Morgan et al., 2000). We show that passive immunization with anti-A $\beta$ antibodies for 3 months reduced amyloid deposits and improved behavioral performance, as indicated by a significant increase in alternation in the $\mathrm{Y}$ maze as well as a decrease in the number of arm entries. The arm entry data suggest that there is not a complete reversal of the increased activity. There is a trend toward some improvement in alternation at the 1 month point (although not significant) despite no reduction in total $\mathrm{A} \beta$ immunohistochemistry. Such improvements may reflect rapid reductions of an $A \beta$ pool (oligomeric?) closely linked to memory impairments yet not easily detected by immunohistochemistry. This phenomenon was previously described by Dodart et al. (2002) and Kotilinek et al. (2002), who showed rapid reversal of memory deficits in transgenic mice after passive immunization without significant reduction in brain $\mathrm{A} \beta$.

The results described above indicating entry of the anti-A $\beta$ antibody into the brain and activation of microglia suggest that some opsonization of $A \beta$ is likely stimulating microglial involvement in the clearance of $\mathrm{A} \beta$ deposits. This is consistent with the phagocytosis mechanisms of amyloid removal put forward by the Elan Phrmaceuticals group (Schenk et al., 1999; Bard et al., 2000, 2003). Our earlier work with direct injection of the anti-A $\beta$ antibody into the brain suggests two mechanisms: one not requiring an Fc component or activation of microglia, which can clear diffuse $\mathrm{A} \beta$, and a second that requires the $\mathrm{Fc}$ domain and activation of microglia (Wilcock et al., 2003, 2004). It is conceivable that the first non-Fc-requiring mechanism is analogous to the catalytic dissolution mechanism described by Solomon et al. (1997). The diffuse material, whatever its state of oligomerization, may be more accessible to this action of anti-A $\beta$ antibodies. Finally, at all durations of antibody exposure, we observed a dramatic increase in circulating $\mathrm{A} \beta$ levels in plasma. This is consistent with a role for the peripheral sink mechanism (DeMattos et al., 2001; Dodart et al., 2002; Lemere et al., 2003) in the reduction of CNS A $\beta$ after passive immunization.

We conclude that our studies using antibody 2286, in aggregate, provide support for all three major proposed mechanisms of anti-A $\beta$ antibody action in lowering brain amyloid. It is essential to recognize that these mechanisms are not mutually exclusive and are likely to be synergistic if multiple mechanisms are elicited by a single antibody or serum. It is also important to recognize that not all monoclonal antibodies need work via all three mechanisms. Both isotype and epitope selectivity could regulate which anti-A $\beta$ action is dominant for a specific antibody. These studies also do not speak to other immune system-related actions that might underlie the benefits (or adverse effects) of active immunization. Nonetheless, given the preliminary data that anti-A $\beta$ immunotherapy may stabilize cognitive function in Alzheimer's patients (Hock et al., 2003) and the consistent reversal of the phenotype found in APP transgenic mice by such approaches, these results support further development of optimal strategies for using anti-A $\beta$ immunotherapy as a treatment for Alzheimer's dementia.

\section{References}

Banks WA, Terrell B, Farr SA, Robinson SM, Nonaka N, Morley JE (2002) Passage of amyloid $\beta$ protein antibody across the blood-brain barrier in a mouse model of Alzheimer's disease. Peptides 23:2223-2226.

Bard F, Cannon C, Barbour R, Burke RL, Games D, Grajeda H, Guido T, Hu
K, Huang J, Johnson-Wood K, Khan K, Kholodenko D, Lee M, Lieberberg I, Motter R, Nguyen M, Soriano F, Vasquez N, Weiss K, Welch B, et al. (2000) Peripherally administered antibodies against amyloid $\beta$-peptide enter the central nervous system and reduce pathology in a mouse model of Alzheimer's disease. Nat Med 6:916-919.

Bard F, Barbour R, Cannon C, Carretto R, Fox M, Games D, Guido T, Hoenow K, Hu K, Johnson-Wood K, Khan K, Kholodenko D, Lee C, Lee M, Motter R, Nguyen M, Reed A, Schenk D, Tang P, Vasquez N, et al. (2003) Epitope and isotype specificities of antibodies to beta-amyloid peptide for protection against Alzheimer's disease-like neuropathology. Proc Natl Acad Sci USA 100:2023-2028.

Das P, Howard V, Loosbrock N, Dickson D, Murphy MP, Golde TE (2003) Amyloid $\beta$ immunization effectively reduces amyloid deposition in FcRgamma-/- knock-out mice. J Neurosci 23:8532-8538.

DeMattos RB, Bales KR, Cummins DJ, Dodart JC, Paul SM, Holtzman DM (2001) Peripheral anti-A $\beta$ antibody alters CNS and plasma $A \beta$ clearance and decreases brain $A \beta$ burden in a mouse model of Alzehimer's disease. Proc Natl Acad Sci USA 98:8850-8855.

Dodart JC, Bales KR, Gannon KS, Greene SJ, DeMattos RB, Mathis C, DeLong CA, Wu S, Wu X, Holtzman DM, Paul SM (2002) Immunization reverses memory deficits without reducing brain Abeta burden in Alzheimer's disease model. Nat Neurosci 5:452-457.

Ferrer I, Boada Rovira M, Sanchez Guerra ML, Rey MJ, Costa-Jussa F (2004) Neuropathology and pathogenesis of encephalitis following amyloid-beta immunization in Alzheimer's disease. Brain Pathol 14:11-20.

Gessner JE, Heiken H, Tamm A, Schmidt RE (1998) The IgG Fc receptor family. Ann Hematol 76:231-248.

Gordon MN, Holcomb LA, Jantzen PT, DiCarlo G, Wilcock D, Boyett KW, Connor K, Melachrino J, O'Callaghan JP, Morgan D (2002) Time course of the development of Alzheimer-like pathology in the doubly transgenic PS1+APP mouse. Exp Neurol 173:183-195.

Hock C, Konietzko U, Papassotiropoulos A, Wollmer A, Streffer J, Von Rotz RC, Davey G, Moritz E, Nitsch RM (2002) Generation of antibodies specific for beta-amyloid by vaccination of patients with Alzheimer disease. Nat Med 8:1270-1275.

Hock C, Konietzko U, Streffer JR, Tracy J, Signorell A, Muller-Tillmanns B, Lemke U, Henke K, Moritz E, Garcia E, Wollmer MA, Umbricht D, de Quervain DJ, Hofmann M, Maddelena A, Papassotiropoulos A, Nitsch RM (2003) Antibodies against beta-amyloid slow cognitive decline in Alzheimer's disease. Neuron 38:547-554.

Holcomb L, Gordon MN, McGowan E, Yu X, Benkovic S, Jantzen P, Wright K, Saad I, Mueller R, Morgan D, Sanders S, Zehr C, O’Campo K, Hardy J, Prada CM, Eckman C, Younkin S, Hsiao K, Duff K (1998) Accelerated Alzheimer-type phenotype in transgenic mice carrying both mutant amyloid precursor protein and presenilin 1 transgenes. Nat Med 4:97-100.

Hsiao K, Chapman P, Nilsen S, Eckman C, Harigaya Y, Younkin S, Yang F, Cole G (1996) Correlative memory deficits, Abeta elevation, and amyloid plaques in transgenic mice. Science 274:99-102.

Janus C, Pearson J, McLaurin J, Mathews PM, Jiang Y, Schmidt SD, Chishti MA, Horne P, Heslin D, French J, Mount HT, Nixon RA, Mercken M, Bergeron C, Fraser PE, George-Hyslop P, Westaway D (2000) A beta peptide immunization reduces behavioural impairment and plaques in a model of Alzheimer's disease. Nature 408:979-982.

Kotilinek LA, Bacskai B, Westerman M, Kawarabayashi T, Younkin L, Hyman BT, Younkin S, Ashe KH (2002) Reversible memory loss in a mouse transgenic model of Alzheimer's disease. J Neurosci 22:6331-6335.

Lemere CA, Spooner ET, LaFrancois J, Malester B, Mori C, Leverone JF, Matsuoka Y, Taylor JW, DeMattos RB, Holtzman DM, Clements JD, Selkoe DJ, Duff KE (2003) Evidence for peripheral clearance of cerebral Abeta protein following chronic, active Abeta immunization in PSAPP mice. Neurobiol Dis $10-18$.

Li Q, Cao C, Chackerian B, Schiller J, Gordon M, Morgan D (2004) Overcoming antigen masking of anti-A $\beta$ antibodies reveals breaking of $B$ cell tolerance by virus-like particles in $\mathrm{A} \beta$ immunized amyloid precursor protein transgenic mice. BMC Neurosci 5:21.

Liu B, Wang K, Gao HM, Mandavilli B, Wang JY, Hong JS (2001) Molecular consequences of activated microglia in the brain: overactivation induces apoptosis. J Neurochem 77:182-189.

Manuelidis L (1998) Vaccination with an attenuated Creutzfeldt-Jakob disease strain prevents expression of a virulent agent. Proc Natl Acad Sci USA 95:2520-2525. 
McMichael AJ, Hanke T (2003) HIV vaccines 1983-2003. Nat Med 9:874-880.

Morgan D, Diamond DM, Gottschall PE, Ugen KE, Dickey C, Hardy J, Duff K, Jantzen P, DiCarlo G, Wilcock D, Connor K, Hatcher J, Hope C, Gordon M, Arendash GW (2000) A beta peptide vaccination prevents memory loss in an animal model of Alzheimer's disease. Nature 408:982-985.

Schenk D, Barbour R, Dunn W, Gordon G, Grajeda H, Guido T, Hu K, Huang J, Johnson-Wood K, Khan K, Kholodenko D, Lee M, Liao Z, Lieberburg I, Motter R, Mutter L, Soriano F, Shopp G, Vasquez N, Vandevert C, et al. (1999) Immunization with amyloid-beta attenuates Alzheimer-diseaselike pathology in the PDAPP mouse. Nature 400:173-177.

Seabrook TJ, Bloom JK, Iglesias M, Spooner ET, Walsh DM, Lemere CA (2004) Species-specific immune response to immunization with human vs. rodent $\mathrm{A} \beta$ peptide. Neurobiol Aging, in press.

Sigurdsson EM, Sy MS, Li R, Scholtzova H, Kascsak RJ, Kascsak R, Carp R, Meeker HC, Frangione B, Wisniewski T (2003) Anti-prion antibodies for prophylaxis following prion exposure in mice. Neurosci Lett 336:185-187.

Solomon B, Koppel R, Frenkel D, Hanan-Aharon E (1997) Disaggregation of Alzheimer beta-amyloid by site-directed monoclonal antibodies. Proc Natl Acad Sci USA 94:4109-4112.

Wilcock DM, Gordon MN, Ugen KE, Gottschall PE, DiCarlo G, Dickey C, Boyett KW, Jantzen PT, Connor KE, Melachrino J, Hardy J, Morgan D (2001) Number of Abeta inoculations in APP+PS1 transgenic mice influences antibody titers, microglial activation, and congophilic plaque levels. DNA Cell Biol 20:731-736.

Wilcock DM, DiCarlo G, Henderson D, Jackson J, Clarke K, Ugen KE, Gordon MN, Morgan D (2003) Intracranially administered anti-A $\beta$ antibodies reduce $\beta$-amyloid deposition by mechanisms independent of and associated with microglial activation. J Neurosci 213:3745-3751.

Wilcock DM, Muniredddy SK, Rosenthal A, Ugen KE, Gordon MN, Morgan D (2004) Microglial activation facilitates A $\beta$ plaque removal following intracranial anti-A $\beta$ antibody administration. Neurobiol Dis 15:11-20. 